\title{
Guideline for Determining the Mean Glandular Dose According to DIN 6868-162 and Threshold Contrast Visibility According to the Quality Assurance Guideline for Digital Mammography Systems
}

\author{
Prüfanleitung für die Bestimmung der mittleren Parenchymdosis nach DIN \\ 6868-162 und des Kontrastauflösungsvermögens nach Qualitätssicherungs- \\ Richtlinie für digitale Mammografieeinrichtungen - Leitfaden der deutschen \\ Referenzzentren für Mammographie Version 2.0
}

Authors

Affiliations
A. Sommer ${ }^{1}$, S. Schopphoven ${ }^{2}$, I. Land ${ }^{3}$, D. Blaser ${ }^{4}$, T. Sobczak ${ }^{5}$

Affiliation addresses are listed at the end of the article.

\begin{abstract}
Key words
- digital mammography

- average glandular dose

- threshold contrast visibility

- CDMAM phantom

- mammography screening
\end{abstract}

received $\quad 8.3 .2013$

accepted $\quad 23.10 .2013$

Bibliography

Dol http://dx.doi.org/

10.1055/s-0033-1356284

Published online: 20.2 .2014

Fortschr Röntgenstr 2014; 186: 474-481 @ Georg Thieme

Verlag KG Stuttgart · New York . ISSN 1438-9029

\section{Correspondence}

Alexander Sommer

Referenzzentrum Mammografie am Universitaetsklinikum Muenster

Albert-Schweitzer-Campus 1

48149 Muenster

Tel.: ++ 49/2 51/8345657

Fax: ++ 49/2 51/8345660

sommer@

referenzzentrum-ms.de

\section{Abstract \\ $\nabla$}

As part of the physico-technical quality assurance of the German breast cancer screening program, the threshold contrast visibility and the average glandular dose of every digital mammography system have to fulfill the requirements of the "European guidelines for quality assurance in breast cancer screening and diagnosis" (4th Edition). To accomplish uniform measurements in all federal states of Germany, the physical board of the reference centers developed a special guideline in 2009. Due to recent changes in the guidelines and standards, a second version of the guideline was developed by the reference centers. This guideline describes the determination of the average glandular dose as well as the CDMAM image acquisition and the CDMAM image evaluation. The determination of the threshold contrast visibility can be performed visually or automatically. The determination of the average glandular dose is based on DIN 6868-162 and the threshold contrast visibility test is based on the German "Quality Assurance Guideline".

Key Points:

- Update of the first guideline due recent changes in the national standards

- Description of the procedure for determining the average glandular dose according to DIN 6868-162

- Description of the procedure for determining the threshold contrast visibility according to the Quality Assurance Guideline

- In addition to the visual evaluation of the threshold contrast visibility, an automatic evaluation method can be used
Citation Format:

- Sommer A, Schopphoven S, Land I et al. Guideline for Determining the Mean Glandular Dose According to DIN 6868-162 and Threshold Contrast Visibility According to the Quality Assurance Guideline for Digital Mammography Systems. Fortschr Röntgenstr 2014; 186 : 474-481

\section{Zusammenfassung \\ $\nabla$}

Im Rahmen der physikalisch-technischen Qualitätssicherung muss nach Beschluss des Bundesministeriums für Umwelt, Naturschutz und Reaktorsicherheit an allen eingesetzten digitalen Mammographiesystemen die Prüfung des Kontrastauflösungsvermögens sowie die Bestimmung der mittleren Parenchymdosis auf Grundlage der „European guidelines for quality assurance in breast cancer screening and diagnosis" 4th Edition durchgeführt werden. Um eine weitgehende Homogenisierung dieser Messungen in Deutschland zu erreichen, wurde von den Referenzzentren für Mammographie bereits 2009 eine gemeinsame Prüfanleitung publiziert. Aufgrund von aktuellen Veränderungen in den Richtlinien und der Normung wurde eine zweite Version durch die Referenzzentren erarbeitet. In dieser Prüfanleitung werden sowohl die einzelnen Schritte zur Bestimmung der mittleren Parenchymdosis als auch die Anfertigung und Auswertung der Prüfkörperaufnahmen für die Ermittlung des Kontrastauflösungsvermögens beschrieben. Die Auswertung der Prüfkörperaufnahmen zur Bestimmung des Kontrastauflösungsvermögens kann hierbei sowohl visuell als auch automatisiert erfolgen. Die Prüfung der Parenchymdosis erfolgt nach den Vorgaben der DIN6868-162 und die Prüfung der Kontrastauflösung nach Vorgaben der QualitätssicherungsRichtlinie. 


\section{Introduction}

\section{$\nabla$}

This guideline describes the procedure for determining the average glandular dose (AGD) according to the standard DIN6868-162:2013 Section 9.12 [1] and the threshold contrast visibility (CDMAM test) according to the currently valid Quality Assurance Guideline for digital mammography systems [2-4]. The procedure described here is used both in quality assurance for the German mammography screening program as well as for systems used for diagnostic mammography [5-7]. This guideline replaces guideline version 1.4 of the German reference centers for mammography [8].

The described tests are based on the specifications of the 4th edition of the "European guidelines for quality assurance in breast cancer screening and diagnosis" (EPQC $4^{\text {th }}$ edition) [9] and the EPQC Supplement [10].

The test and measurement equipment of DIN 6868-162 is to be used for determining the AGD. The test of the threshold contrast visibility is to be performed using a test object in accordance with EPQC $4^{\text {th }}$ edition.

This guideline was coordinated among all German mammography reference centers.

The original text of the guideline contains various appendices with practical procedures and examples of the individual test positions.

\section{Determination of the average glandular dose according to DIN 6868 - 162 Number 9.12 [1]}

The AGD is determined according to the following procedure: exposure control (AEC)

2. Determination of the entrance surface air kerma using manual exposure settings

3. Determination of the half-value layer (HVL)

4. Determination of the factors $\mathrm{g}, \mathrm{c}$, and $\mathrm{s}$

5. Calculation of the AGD
1. Determination of the imaging conditions with automatic

If a mammography system has more than one breast support table, each with a different AEC-detector attached, then each AEC system must be assessed separately.

\subsection{Determination of the imaging conditions}

The exposure factors (target-filter combination, x-ray tube voltage, tube loading) are determined using the test blocks of polymethyl methacrylate (PMMA) specified in DIN 6868 162 Appendix A d) [1].

For each of seven different PMMA thicknesses, one X-ray is acquired using the AEC exposure settings that are normally used clinically for the particular equivalent breast thickness according to $\bullet$ Table 1 ( $\bullet$ Fig. 1 a).

If a correction switch is provided for clinical operation, it must be set to the position that is normally used clinically. The imaging conditions including the tube loading ( $\mathrm{mAs}$ ) set by the automatic exposure control are recorded for every X-ray.

\subsubsection{Positioning of the AEC-detector}

In mammography systems with a manually selectable AEC-detector position of the automatic exposure control, the detector must be positioned near the chest wall. The effective measurement field of the detector must be completely under the particular attenuation body and remain in the same position during every exposure. An automatically selected measurement field position AEC is only per-

Table 1 Limiting values of the average glandular dose.

\begin{tabular}{|lll|}
$\begin{array}{l}\text { object thickness } \\
\text { PMMA (mm) }\end{array}$ & $\begin{array}{l}\text { equivalent breast } \\
\text { thickness (mm) }\end{array}$ & $\begin{array}{l}\text { limit value of the average } \\
\text { glandular dose (mGy) }\end{array}$ \\
\hline $20 \mathrm{~mm}$ & $21 \mathrm{~mm}$ & 1.0 \\
\hline $30 \mathrm{~mm}$ & $32 \mathrm{~mm}$ & 1.5 \\
\hline $40 \mathrm{~mm}$ & $45 \mathrm{~mm}$ & 2.0 \\
\hline $46 \mathrm{~mm}$ & $53 \mathrm{~mm}$ & 2.5 \\
\hline $50 \mathrm{~mm}$ & $60 \mathrm{~mm}$ & 3.0 \\
\hline $60 \mathrm{~mm}$ & $75 \mathrm{~mm}$ & 4.5 \\
\hline $70 \mathrm{~mm}$ & $90 \mathrm{~mm}$ & 6.5 \\
\hline
\end{tabular}

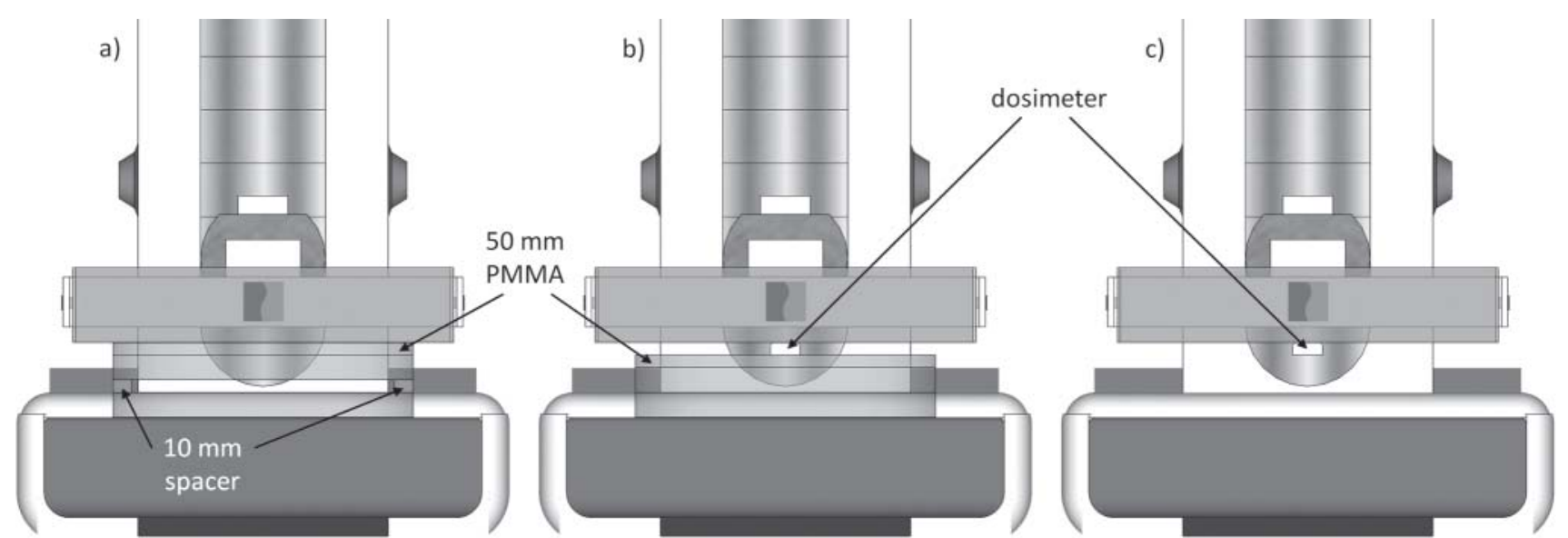

Fig. 1 Example for 50-mm PMMA thickness according to Table 1: Determination of the exposure conditions with a) 50-mm PMMA attenuation body and $10-\mathrm{mm}$ spacer for simulation of 60 - $\mathrm{mm}$ breast tissue, b) meas- urement of the entrance surface air kerma KE with 50-mm PMMA attenuation body and c) measurement of the entrance surface air kerma KE without a PMMA attenuation body. 
mitted for mammography systems that do not allow selection of the AEC-detector position.

\subsubsection{Spacer}

For mammography systems that select the exposure parameters in AEC mode as a function of the object thickness, the total thickness must be corrected to the equivalent breast thickness according to $\triangle$ Table 1 in order to simulate the conditions in clinical operation. Spacers that do not interfere with radiography can be used for this purpose (० Fig.1a).

\subsection{Determination of the entrance surface air kerma $K_{E}$} For all seven PMMA thicknesses according to $\bullet$ Table 1, the entrance surface air kerma $K_{E}$ is determined at the upper surface of the PMMA test object (without spacers) in manual mode ( $\bullet$ Fig. 1b).

The measurement chamber of the dosimeter is to be positioned $6 \mathrm{~cm}$ from the chest wall side and laterally centered. The radiation detector of the dosimeter and the bottom of the compression plate must be in contact during the measurements. Scattered radiation from the test objects must not contribute to the measurement results.

The target-filter combination, tube voltage, and the tube loading used in manual mode are to be taken from the corresponding exposures in AEC mode with automatic exposure control (see 2.1). The selectable tube loading closest to the $\mathrm{mAs}$ value $(\mathrm{Q})$ of the corresponding PMMA thickness determined under 2.1 is to be used for the tube loading.

If the nearest selectable tube loading deviates more than $5 \%$ from the mAs value determined according to 2.1, the entrance surface air kerma is determined twice for the corresponding PMMA thickness, once with the next high mAs value and once with the next low mAs value. The entrance surface air kerma $K_{E}$ is then calculated via linear interpolation for the tube loading determined in 2.1.

Example 1: Linear interpolation of entrance surface air kerma $K_{E}$

Assumption:An $\mathrm{mAs}$ value of $\mathrm{Q}=74.8$ was determined for a PMMA thickness of $50 \mathrm{~mm}$ according to section 2.1.

1. Determination of the deviation from the nearest selectable tube loading.

In manual mode, the nearest selectable tube loading is $70 \mathrm{mAs}$. Since $70 \mathrm{mAs}$ deviates more than $5 \%$ from $74.8 \mathrm{mAs}$, the entrance surface air kerma is measured for both $Q_{1}=70 \mathrm{mAs}$ (next low selectable $\mathrm{mAs}$ value) and $Q_{2}=80 \mathrm{mAs}$ (next high selectable mAs value).

2. Linear interpolation of entrance surface air kerma $K_{E}$

The measurements result in an entrance surface air kerma of $K_{E, 1}=4.586 \mathrm{mGy}$ for $\mathrm{Q}_{1}=70 \mathrm{mAs}$ and $\mathrm{K}_{\mathrm{E}, 2}=5.241 \mathrm{mGy}$ for $\mathrm{Q}_{2}=80 \mathrm{mAs}$. Using linear interpolation entrance surface air kerma dose $K_{E}$ for $Q=74.8 \mathrm{mAs}$ is determined to be:

$\mathrm{K}_{\mathrm{E}}=\mathrm{K}_{\mathrm{E}, 1}+\frac{\mathrm{K}_{\mathrm{E}, 2}-\mathrm{K}_{\mathrm{E}, 1}}{\mathrm{Q}_{2}-\mathrm{Q}_{1}} \cdot\left(\mathrm{Q}-\mathrm{Q}_{1}\right)$

$\mathrm{K}_{\mathrm{E}}=4,586 \mathrm{mGy}+\frac{5,241 \mathrm{mGy}-4,586 \mathrm{mGy}}{80 \mathrm{mAs}-70 \mathrm{mAs}} \cdot(74,8 \mathrm{mAs}-70 \mathrm{mAs})$

Alternatively, the measurements can be performed without PMMA test objects. The measurement chamber of the dosimeter is positioned in contact with the bottom of the compression plate $(6 \mathrm{~cm}$ from the edge on the chest wall side, in the center of the side). The distance between the breast support table and the bottom of the dosimeter must correspond to the PMMA thickness according to Table 1 (ه Fig. 1c).

\subsection{Determination of the half-value layer (HVL)}

The half-value layer (HVL) must be determined for the exposure factors (target-filter combination, X-ray tube voltage, tube loading) determined in 2.1. A compression plate must be located in the beam.

The HVL must be determined using one of the following procedures:

- Direct measurement of the HVL with a digital HVL-meter (see section 2.3.1)

- Polynomial interpolation using tabulated values (see section 2.3.2).

\subsubsection{Direct measurement of the HVL}

Direct measurement of the HVL can be performed in combination with the determination of the entrance surface air kerma according to 2.2 (for all seven PMMA thicknesses).

\subsubsection{Polynomial interpolation of the HVL}

Alternatively, the corresponding HVL values can be determined using the procedure described by Robson [11]. This includes a two-step method based on the parameters of - Table 2:

$H V L=a \cdot U^{2}+b \cdot U+d$

with

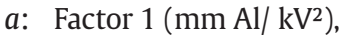

b: Factor $2(\mathrm{~mm} \mathrm{Al} / \mathrm{kV})$,

$d$ : Intercept point $(\mathrm{mm} \mathrm{Al})$

$U$ : X-ray tube voltage $(\mathrm{kV})$

1. Determination of $d$ for the HVL measured according to DIN 6868 - 162 test point 9.2 [1]. Equation (2) must be solved for $d$ and the corresponding values from $\bullet$ Table 2 are to be entered (see example 2).

2. Interpolation of the HVL for the required X-ray tube voltage via equation (2). The corresponding X-ray tube voltage is used for this purpose and the value determined in step 1 for $d$ is entered in equation (2) (see example 2).

Example 2: Interpolation of the $H V L$ for $30 \mathrm{kV} \mathrm{Mo} / \mathrm{Mo}$ with a measured $H V L$ of $0.35 \mathrm{~mm} \mathrm{Al}$ for $28 \mathrm{kV} \mathrm{Mo/Mo.}$

1. Determination of $d$ for $28 \mathrm{kV}$ Mo/Mo

$\mathrm{d}=\mathrm{HVL}-\mathrm{a} \cdot \mathrm{U}^{2}-\mathrm{b} \cdot \mathrm{U}$

$\mathrm{d}=\left(0,35 \mathrm{~mm} \mathrm{Al}-\left(-0,00027778 \frac{\mathrm{mmAl}}{\mathrm{kV}^{2}} \cdot(28 \mathrm{kV})^{2}\right)-\left(0,02605556 \frac{\mathrm{mmAl}}{\mathrm{kV}} \cdot 28 \mathrm{kV}\right)\right)$

$\mathrm{d}=-0,16178 \mathrm{~mm} \mathrm{AL}$

Table 2 Factors $a$ and $b$ for polynomial interpolation of the HVL as a function of the voltage according to equation 2. The factors were based on DIN 6868 162 [1], Table 2.

\begin{tabular}{|c|c|c|}
\hline target and filter & $\begin{array}{l}\text { factor } 1[a] \\
\left(\mathrm{mm} \mathrm{Al} / \mathbf{k V}^{2}\right)\end{array}$ & $\begin{array}{l}\text { factor } 2 \text { [b] } \\
\text { (mm Al/kV) }\end{array}$ \\
\hline $\mathrm{Mo}+30 \mu \mathrm{m} \mathrm{Mo}$ & -0.00027778 & 0.02605556 \\
\hline $\mathrm{Mo}+25 \mu \mathrm{m} \mathrm{Rh}$ & -0.00027778 & 0.02538889 \\
\hline $\mathrm{Rh}+25 \mu \mathrm{m} \mathrm{Rh}$ & -0.00083333 & 0.06483333 \\
\hline$W+50 \mu \mathrm{m} R \mathrm{Rh}$ & 0.00000000 & 0.01000000 \\
\hline $\mathrm{W}+50 \mu \mathrm{m} \mathrm{Ag}$ & -0.00111111 & 0.08222222 \\
\hline $\mathrm{W}+0.5 \mathrm{~mm} \mathrm{Al}$ & -0.00027778 & 0.03538889 \\
\hline
\end{tabular}


Table 3 g-factors for breast simulation with PMMA (conversion to $50 \%$ glandular tissue) $[12,13]$.

\begin{tabular}{|c|c|c|c|c|c|c|c|c|c|c|c|c|c|}
\hline \multirow{3}{*}{$\begin{array}{l}\text { PMMA } \\
\text { thickness } \\
\text { (mm) }\end{array}$} & \multirow{3}{*}{$\begin{array}{l}\text { equivalent } \\
\text { breast thickness } \\
(\mathrm{mm})\end{array}$} & \multirow{3}{*}{$\begin{array}{l}\text { glandularity of } \\
\text { the equivalent } \\
\text { breast thickness }\end{array}$} & \multicolumn{11}{|c|}{$g$-factors (mGy/mGy) } \\
\hline & & & \multicolumn{11}{|c|}{ HVL (mm Al) } \\
\hline & & & 0.30 & 0.35 & 0.40 & 0.45 & 0.50 & 0.55 & 0.60 & 0.65 & 0.70 & 0.75 & 0.80 \\
\hline 20 & 21 & 97 & 0.378 & 0.421 & 0.46 & 0.496 & 0.529 & 0.559 & 0.585 & 0.609 & 0.631 & 0.65 & 0.669 \\
\hline 30 & 32 & 67 & 0.261 & 0.294 & 0.326 & 0.357 & 0.388 & 0.419 & 0.448 & 0.473 & 0.495 & 0.516 & 0.536 \\
\hline 40 & 45 & 41 & 0.183 & 0.208 & 0.232 & 0.258 & 0.285 & 0.311 & 0.339 & 0.366 & 0.387 & 0.406 & 0.425 \\
\hline 45 & 53 & 29 & 0.155 & 0.177 & 0.198 & 0.22 & 0.245 & 0.272 & 0.295 & 0.317 & 0.336 & 0.354 & 0.372 \\
\hline 50 & 60 & 20 & 0.135 & 0.154 & 0.172 & 0.192 & 0.214 & 0.236 & 0.261 & 0.282 & 0.3 & 0.317 & 0.333 \\
\hline 60 & 75 & 9 & 0.106 & 0.121 & 0.136 & 0.152 & 0.166 & 0.189 & 0.21 & 0.228 & 0.243 & 0.257 & 0.272 \\
\hline 70 & 90 & 4 & 0.086 & 0.098 & 0.111 & 0.123 & 0.136 & 0.154 & 0.172 & 0.188 & 0.202 & 0.214 & 0.227 \\
\hline 80 & 103 & 3 & 0.074 & 0.085 & 0.096 & 0.106 & 0.117 & 0.133 & 0.149 & 0.163 & 0.176 & 0.187 & 0.199 \\
\hline
\end{tabular}

\begin{tabular}{|c|c|c|c|c|c|c|c|c|c|c|c|c|c|}
\hline \multirow{3}{*}{$\begin{array}{l}\text { PMMA } \\
\text { thickness } \\
(\mathrm{mm})\end{array}$} & \multirow{3}{*}{$\begin{array}{l}\text { equivalent } \\
\text { breast thickness } \\
(\mathrm{mm})\end{array}$} & \multirow{3}{*}{$\begin{array}{l}\text { glandularity of } \\
\text { the equivalent } \\
\text { breast thickness }\end{array}$} & \multicolumn{11}{|c|}{ c-factors } \\
\hline & & & \multicolumn{11}{|c|}{ HVL (mm Al) } \\
\hline & & & 0.30 & 0.35 & 0.40 & 0.45 & 0.50 & 0.55 & 0.60 & 0.65 & 0.70 & 0.75 & 0.80 \\
\hline 20 & 21 & 97 & 0.889 & 0.895 & 0.903 & 0.908 & 0.912 & 0.917 & 0.921 & 0.924 & 0.928 & 0.933 & 0.937 \\
\hline 30 & 32 & 67 & 0.94 & 0.943 & 0.945 & 0.946 & 0.949 & 0.952 & 0.953 & 0.956 & 0.959 & 0.961 & 0.964 \\
\hline 40 & 45 & 41 & 1.043 & 1.041 & 1.040 & 1.039 & 1.037 & 1.035 & 1.034 & 1.032 & 1.030 & 1.028 & 1.026 \\
\hline 45 & 53 & 29 & 1.109 & 1.105 & 1.102 & 1.099 & 1.096 & 1.091 & 1.088 & 1.082 & 1.078 & 1.073 & 1.068 \\
\hline 50 & 60 & 20 & 1.164 & 1.160 & 1.151 & 1.150 & 1.144 & 1.139 & 1.134 & 1.124 & 1.117 & 1.111 & 1.103 \\
\hline 60 & 75 & 9 & 1.254 & 1.245 & 1.235 & 1.231 & 1.225 & 1.217 & 1.207 & 1.196 & 1.186 & 1.175 & 1.164 \\
\hline 70 & 90 & 4 & 1.299 & 1.292 & 1.282 & 1.275 & 1.270 & 1.260 & 1.249 & 1.236 & 1.225 & 1.213 & 1.200 \\
\hline 80 & 103 & 3 & 1.307 & 1.299 & 1.292 & 1.287 & 1.283 & 1.273 & 1.262 & 1.249 & 1.238 & 1.226 & 1.213 \\
\hline
\end{tabular}

Table 5 s-factors for clinically used target-filter combinations (correction for the X-ray spectrum). Right (column 3 and 4): s-factors for systems with W/ Al combination filtered with $0.5 \mathrm{~mm} \mathrm{Al}[12,14]$.

\begin{tabular}{|llll|}
\hline target and filter & s-factors & PMMA (mm) & s-factors for W/Al \\
\hline Mo $+30 \mu \mathrm{m} \mathrm{Mo}$ & 1.000 & 20 & 1.075 \\
\hline $\mathrm{Mo}+25 \mu \mathrm{m} \mathrm{Rh}$ & 1.017 & 30 & 1.104 \\
\hline $\mathrm{Rh}+25 \mu \mathrm{m} \mathrm{Rh}$ & 1.061 & 40 & 1.134 \\
\hline $\mathrm{W}+50 \mu \mathrm{m} \mathrm{Rh}$ & 1.042 & 45 & 1.149 \\
\hline $\mathrm{W}+50 \mu \mathrm{m} \mathrm{Ag}$ & 1.042 & 50 & 1.160 \\
\hline & & 60 & 1.181 \\
\hline & & 70 & 1.198 \\
\hline
\end{tabular}

\section{Interpolation of $\mathrm{HVL}$ for $30 \mathrm{kV} \mathrm{Mo} / \mathrm{Mo}$}

$\mathrm{HVL}=\mathrm{a} \cdot \mathrm{U}^{2}+\mathrm{b} \cdot \mathrm{U}+\mathrm{d}$

$\mathrm{HVL}=0,37 \mathrm{~mm}$ AL

$H V L=\left(\left(-0,00027778 \frac{\mathrm{mm} \mathrm{Al}}{\mathrm{kV}^{2}} \cdot(30 \mathrm{kV})^{2}\right)+\left(0,02605556 \frac{\mathrm{mm} \mathrm{Al}}{\mathrm{kV}} \cdot 30 \mathrm{kV}\right)+(-0,16178 \mathrm{~mm} \mathrm{Al})\right)$

\subsection{Calculation of the average glandular dose}

The AGD values are to be calculated for the seven entrance surface air kerma $K_{E}$ measured according to section 2.2 by applying the following equation (3) [12]:

$A G D=K_{E} \cdot g \cdot C \cdot S$ with

$K_{\mathrm{E}}$ Entrance surface air kerma determined according to section 2.2

$g$ Factor for the conversion to $50 \%$ glandular tissue,

c Factor for the correction of the deviation of the composition of real breasts from the $50 \%$ glandular tissue proportion,

$s$ Factor for the correction of the deviation based on the selection of the target-filter combination with significant influence on the X-ray spectrum.

The factors $g, c$ and $s$ can be taken from $\bullet$ Table $3-5$. Factors $g$ and $c$ are selected for the HVLs determined in section 2.3. For HVL values that are not contained in 0 Table 3 and - Table 4, factors $g$ and $c$ are calculated via polynomial interpolation.

\subsection{Requirements and evaluation}

The AGD values determined in section 2.4 must not exceed the limiting values of the average glandular dose according to $\odot$ Table 1.

\section{Determination of the threshold contrast visibility according to the Quality Assurance Guideline [2]}

The threshold contrast visibility is determined using the CDMAM test object according to the $4^{\text {th }}$ edition of the "European guidelines for quality assurance in breast cancer screening and diagnosis" (EPQC) from 2006 (० Fig.2) [9].

The test procedure described in EPQC Section 2b.2.4.1 [9] (test procedure $\mathrm{A}$ ) or alternatively the test procedure speci- 


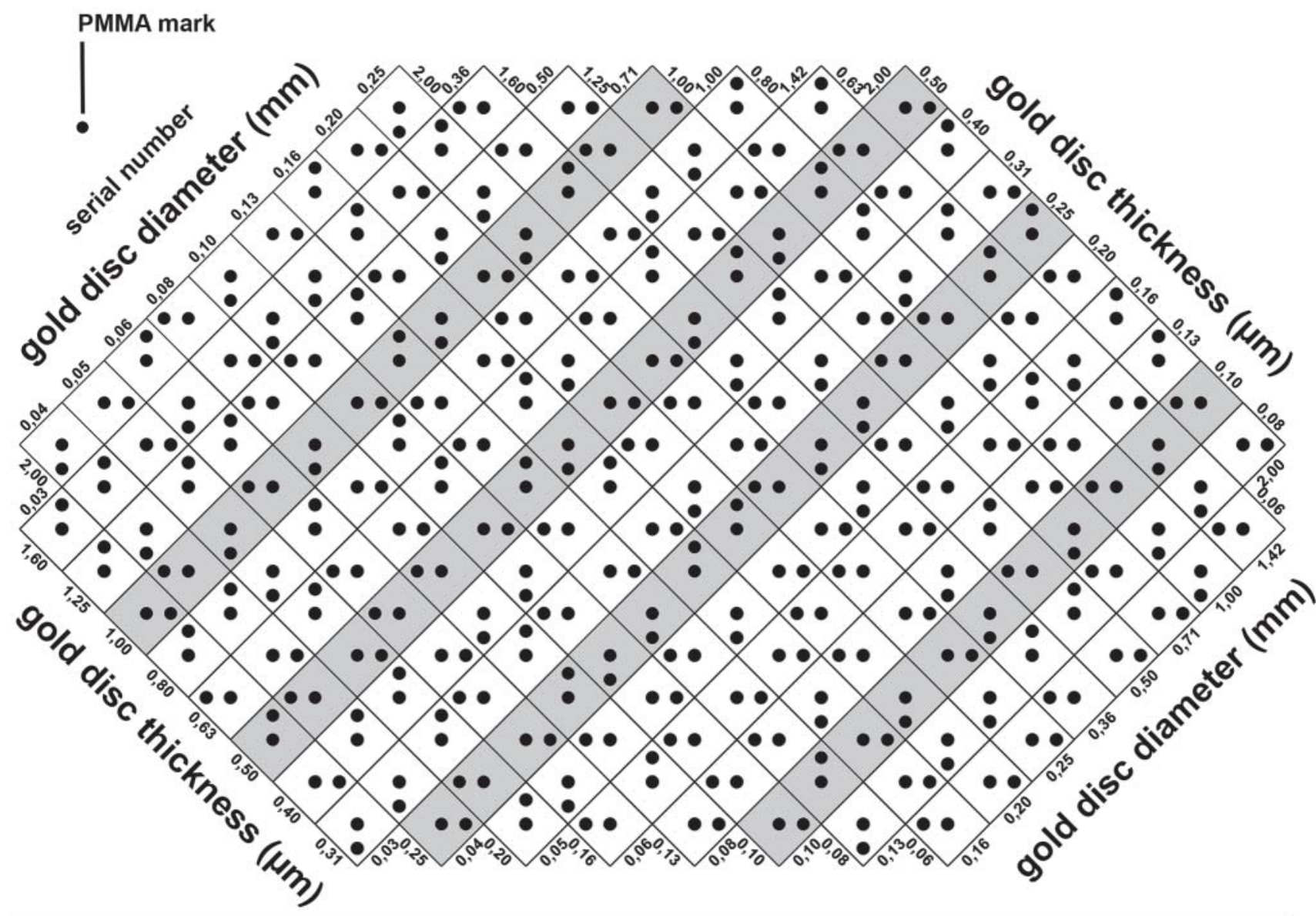

\section{chest wall}

Fig. 2 Schema and alignment of the CDMAM phantom [17].

fied in EPQC Supplement S1 Part 1 Section 2b.2.4.1 [10] (test procedure $\mathrm{B}$ ) is to be used for the evaluation of the acquired images.

\subsection{Requirements for the determination of the threshold contrast visibility}

The AGD determined in section 2.4 for a $50 \mathrm{~mm}$ PMMA must not exceed the value of $3 \mathrm{mGy}$ according to DIN 6868 - 162 ( $\bullet$ Table 1 ).

According to a memorandum of the Federal Ministry for the Environment, Nature Conservation, and Nuclear Safety dated 2/27/2008 [15], one of the observers must be an appropriately trained expert (certified CDMAM training course as of $4 / 1 / 2008$, right of continuance for CDMAM courses prior to $4 / 1 / 2008)$.

The visual evaluation of the test object images is to be performed on site using image display devices that meet the specifications of DIN V 6868 - 57 [16] and the Quality Assurance Guideline. The evaluation may only be performed on other image display devices that meet the above specifications if a diagnostic workstation is not available on site (e. g. Mammobil, reporting at an external location).

\subsection{Determination of the exposure factors}

The absorption behavior of the CDMAM test object ( $45 \mathrm{~mm}$ thickness) corresponds to $50 \mathrm{~mm}$ of homogeneous PMMA.
Therefore, the test object images are acquired in manual mode with the parameters determined in section 2.1. for a PMMA thickness of $50 \mathrm{~mm}$ ( $60 \mathrm{~mm}$ equivalent breast thickness).

If the tube loading determined under 2.1 for $50 \mathrm{~mm}$ PMMA, is not in AEC mode manually selectable, the next smaller mAs value has to be used.

\subsection{Arrangement of the test object}

The 5-mm contrast detail plate is to be covered above and below with 20-mm PMMA using the four included $10-\mathrm{mm}$ PMMA plates. The markings of the PMMA plates and the serial number of the contrast detail plate must be positioned on the left side distal from the chest wall. The phantom must be aligned with the chest wall edge of the breast support table and be positioned laterally centered.

\subsection{Test procedure $A$ (visual evaluation)}

\subsubsection{Acquisition of the phantom images}

Six X-rays of the CDMAM phantom are to be acquired using the same exposure parameters determined under 3.2 for all images. The test object is to be moved a few millimeters along the longitudinal and transverse axis of the breast support table between the individual exposures. 
The images acquired for the visual evaluation must be processed with the same image processing method used for clinical mammograms.

\subsubsection{Visual evaluation of the phantom images}

The six CDMAM phantom images are evaluated by three different observers meeting the following criteria:

1. One of the observers must be a trained expert [15].

2. The two other observers must both have experience with radiological applications (e.g. radiology specialist, medical physics expert, physician with mammography experience).

After receiving instructions from the expert, each observer independently evaluates two of the six images under the supervision of the expert. Not all rows of the CDMAM test object need to be evaluated. The following rows of the gold disc diameter required in EPQC 4th edition Part B must be evaluated: $0.10 \mathrm{~mm} ; 0.25 \mathrm{~mm} ; 0.50 \mathrm{~mm}$ und $1.00 \mathrm{~mm}$.

In every field of the four indicated rows, the central and peripheral gold discs must be visible. The individual fields of the rows must be continuously correctly seen starting from the thickest gold disc.

To optimize the visibility of the individual gold discs, it is permitted to use the digital postprocessing options available for interpreting mammograms (e.g. windowing, magnification, inversion, etc.).

Neighbor correction

Each field of the CDMAM test object has a maximum of four directly adjacent fields. For a gold disc thickness to be considered "seen", the following rules must be followed:

1. A detected field is only evaluated as "seen" if at least two directly adjacent fields were also correctly detected.

2. An undetected field can nonetheless be rated as "seen" if at least 3 directly adjacent fields were also correctly detected.

3. An exception to rules 1 and 2 is permitted when a field has less than 4 directly adjacent fields due to its position in the test object.

Example for rules 1 and 3:

4 directly adjacent fields are present $=2$ adjacent fields must be correctly detected;

3 directly adjacent fields are present $=$ only 1 adjacent field must be correctly detected;

2 directly adjacent fields are present $=$ the field can be evaluated as "seen" without any additional correctly detected adjacent fields.

\section{Example for rules 2 and 3:}

4 directly adjacent fields $=3$ adjacent fields must be correctly detected;

3 directly adjacent fields $=2$ adjacent fields must be correctly detected;

2 directly adjacent fields = only 1 adjacent field must be correctly detected;

The smallest visible (i.e., evaluated as "seen") gold disc thicknesses determined according to this principle are to be documented for each of the four rows and for each of the six exposures ( $\bullet$ Table 6 ).

\begin{tabular}{|c|c|c|c|c|}
\hline gold disc (GD) $\emptyset$ & $0.10 \mathrm{~mm}$ & $0.25 \mathrm{~mm}$ & $0.50 \mathrm{~mm}$ & $1.00 \mathrm{~mm}$ \\
\hline exposure $1 \mathrm{GD}$ thickness $(\mu \mathrm{m})$ & 2.00 & 0.25 & 0.13 & 0.08 \\
\hline exposure $2 \mathrm{GD}$ thickness $(\mu \mathrm{m})$ & 2.00 & 0.25 & 0.13 & 0.08 \\
\hline exposure 3 GD thickness ( $\mu \mathrm{m})$ & 2.00 & 0.50 & 0.16 & 0.10 \\
\hline exposure 4 GD thickness ( $\mu \mathrm{m})$ & 1.42 & 0.36 & 0.13 & 0.08 \\
\hline exposure $5 \mathrm{GD}$ thickness $(\mu \mathrm{m})$ & 1.42 & 0.36 & 0.13 & 0.10 \\
\hline exposure 6 GD thickness $(\mu \mathrm{m})$ & 1.42 & 0.25 & 0.13 & 0.08 \\
\hline mean value GD thickness $(\mu \mathrm{m})$ : & 1.710 & 0.328 & 0.135 & 0.087 \\
\hline limit value EPQC $4^{\text {th }} \mathrm{Ed} .(\mu \mathrm{m})$ : & 1.680 & 0.352 & 0.150 & 0.091 \\
\hline condition met ${ }^{1)}$ : & no & yes & yes & yes \\
\hline
\end{tabular}

Table 7 Minimum requirement for the smallest visible gold disc thickness $(\mu \mathrm{m})$ according to EPQC $4^{\text {th }}$ edition [9].

\begin{tabular}{|lll}
$\begin{array}{l}\text { gold disc } \\
\text { diameter }(\mathbf{m m})\end{array}$ & $\begin{array}{l}\text { limiting value: Gold disc } \\
\text { thickness }(\mu \mathrm{m}) \text { according } \\
\text { to EPQC 4th edition }\end{array}$ & $\begin{array}{l}\text { next smaller gold disc } \\
\text { thickness }(\mu \mathrm{m}) \text { compared } \\
\text { to the limit value }\end{array}$ \\
\hline 0.10 & $\leq 1.680$ & 1.42 \\
\hline 0.25 & $\leq 0.352$ & 0.25 \\
\hline 0.50 & $\leq 0.150$ & 0.13 \\
\hline 1.00 & $\leq 0.091$ & 0.08 \\
\hline
\end{tabular}

\subsubsection{Requirements and evaluation}

The mean is calculated for each gold disc diameter from the six determined smallest visible gold disc thicknesses (o Table 6).

The threshold contrast visibilty test is considered to have been passed when the mean values of the smallest visible gold disc thicknesses for the four gold disc diameters $(0.10 \mathrm{~mm} ; 0.25 \mathrm{~mm} ; 0.50 \mathrm{~mm} ; 1.00 \mathrm{~mm})$ do not exceed the limiting values of 0 Table 7 .

In the case of a negative contrast resolution test result, it is allowed to repeat the test with the original data (DICOM for processing) in order to rule out interfering structures possibly caused by image processing. In the case of a positive result with the original data, the test is considered to have been passed.

\subsubsection{Documentation according to test procedure $\mathrm{A}$}

The following data are to be documented:

1. Exposure factors (target-filter combination, $\mathrm{kV}, \mathrm{mAs}$, format)

2. Postprocessing method used

3. Serial number of the test object

4. Certified expert

5. Observers

6. Image display devices or diagnostic workstation used for visual evaluation

7. Position of the detected gold structures

8. Determined contrast detail resolution per tested diameter incl. neighbor correction (refer to 3.4.2)

9. Overall test result (passed/failed).

\subsection{Test procedure B (automatic evaluation)}

3.5.1 Acquisition of the test object images

At least sixteen X-rays of the CDMAM phantom are to be acquired using the same exposure parameters determined under 3.2 for all images. The phantom is moved a few milli- 
Table 8 Sample automatic evaluation results.

\begin{tabular}{|llll|}
$\begin{array}{l}\text { Diameter } \\
(\mathbf{m m})\end{array}$ & $\begin{array}{l}\text { Automatic } \\
\text { threshold gold } \\
\text { thickness }(\boldsymbol{\mu m})\end{array}$ & $\begin{array}{l}\text { Predicted human } \\
\text { gold thickness } \\
(\boldsymbol{\mu m})\end{array}$ & $\begin{array}{l}\text { Fit to predicted } \\
\text { gold thickness } \\
(\boldsymbol{\mu m})\end{array}$ \\
\hline 0.08 & 1.111 & 1.650 & 1.217 \\
\hline 0.10 & 0.579 & 0.893 & 0.867 \\
\hline 0.13 & 0.343 & 0.554 & 0.583 \\
\hline 0.16 & 0.233 & 0.394 & 0.433 \\
\hline 0.20 & 0.187 & 0.329 & 0.316 \\
\hline 0.25 & 0.148 & 0.270 & 0.236 \\
\hline 0.31 & 0.100 & 0.190 & 0.181 \\
\hline 0.40 & 0.064 & 0.128 & 0.135 \\
\hline 0.50 & 0.049 & 0.102 & 0.107 \\
\hline 0.63 & 0.038 & 0.084 & 0.086 \\
\hline 0.80 & 0.031 & 0.072 & 0.071 \\
\hline 1.00 & 0.026 & 0.063 & 0.062 \\
\hline
\end{tabular}

meters along the longitudinal and transverse axis of the patient positioning aid between the individual exposures. Original data of the phantom images (DICOM for processing) are used for the evaluation according to test procedure B. All exposures are evaluated automatically.

In addition, a plausibility test is performed by analysing one of the images according to test procedure A (see 3.4).

\subsubsection{Automatic evaluation of the test object exposures}

The "CDMAM analysis" software is used for the automatic evaluation (www.euref.org/downloads). Version v1.5.5 or higher must be used. Information regarding the installation and use of the software is available in the software user manual.

Since the results of the automatic evaluation (automatic threshold gold thickness) cannot be directly compared to the visual detection of the gold discs, the result is adapted to a typical human observer (predicted human gold thickness) using the CDMAM Analysis Software Tool. The contrast detail curve is then calculated by curve fitting (fit to predicted gold thickness) via a $3^{\text {rd }}$ degree polynomial. The software uses the method of Young et al. (UK method) for this [18].

\subsubsection{Determination of threshold contrast visibility}

The results of the adapted and fitted automatic evaluation (fit to predicted gold thickness) are documented for the four rows of the gold disc diameters $(0.10 \mathrm{~mm} ; 0.25 \mathrm{~mm}$; $0.50 \mathrm{~mm}$; and $1.00 \mathrm{~mm}$ ) required by the EPQC Supplement (0 Table 8).

\subsubsection{Requirements and evaluation}

A check must be performed to ensure that the results documented under 3.5.3 do not exceed the limiting values in - Table 7. In the case of a negative result, the contrast resolution test is considered to have failed. In the case of a positive result of the automatic evaluation, this must be subjected to a visual plausibility check according to test procedure A. The contrast resolution test is considered to have been passed when the next lower gold disc thickness for every examined row according to $\bullet$ Table 7 was "seen" in the comparison to the limit value in one of the 16 exposures (refer to section 3.4.2). The test can be performed using the origi- nal data with a corresponding adaptation of brightness and contrast.

In case of justified suspicion regarding the plausibility of the results of the automatic evaluation, a complete test according to procedure $\mathrm{A}$ has to be performed (refer to 3.4).

\subsubsection{Documentation according to test procedure B}

The following data are to be documented:

1. Exposure factors (target-filter combination, $\mathrm{kV}, \mathrm{mAs}$, format)

2. Postprocessing used for the image evaluated according to test procedure $\mathrm{A}$

3. Serial number of the test object

4. Certified expert

5. Version of the CDMAM analysis sofware

6 . Determined contrast detail resolution per tested diameter

7. Results of visual check according to test procedure $A$

8. Image display devices or diagnostic workstation used for visual evaluation

9. Overall test result (passed/failed).

\section{Affiliations}

1 Physical-technical quality assurance group, Reference Center Muenster for Mammography at the University Hospital Muenster;

2 Physical-technical quality assurance group, Reference Center for Mammography Southwest in Marburg;

3 Physical-technical quality assurance group, Reference Center for Mammography in Berlin;

${ }^{4}$ Physical-technical quality assurance group, Reference Center for Mammography in Munich;

5 Physical-technical quality assurance group, Reference Center for Mammography Nord in Oldenburg;

\section{References}

1 Normenausschuss Radiologie (NAR). DIN 6868-162; Sicherung der Bildqualität in röntgendiagnostischen Betrieben - Teil 162: Abnahmeprüfung nach RöV an Röntgeneinrichtungen für digitale Mammographie. Juni 2013

2 Qualitätssicherungs-Richtlinie (QS-RL) zur Durchführung der Qualitätssicherung bei Röntgeneinrichtungen zur Untersuchung oder Behandlung von Menschen nach den $\S \S 16$ und 17 der Röntgenverordnung

3 Czwoydzinski J, Girnus R, Sommer A et al. Zentrale Online-Qualitätssicherung in der Radiologie: eine IT-Lösung am Beispiel des deutschen Mammografie-Screening-Programms. Fortschr Röntgenstr 2011; 183: $849-854$

4 Schreiter NF, Steffen IG, Miller J et al. Qualitative JPEG 2000 compression in digital mammography - evaluation using 480 mammograms of the CDMAM phantom. Fortschr Röntgenstr 2011; 183: 650-657

5 Semturs F, Peloschek P, Zwettler G et al. Nadelkristalldetektor-Technologie in der Mammografie - Bildqualität und Dosisverhalten in Abhängigkeit von der Strahlenqualität. Fortschr Röntgenstr 2012; 184: 905-910

6 Waldmann A, Adrich S, Eisemann $N$ et al. Struktur- und Prozessqualitat in der qualitatsgesicherten Mammadiagnostik in Schleswig-Holstein. Fortschr Röntgenstr 2012; 184: 113-121

7 Weigel S, Decker T, Korsching E et al. Minimal invasive biopsy results of "uncertain malignant potential" in digital mammography screening: high prevalence but also high predictive value for malignancy. Fortschr Röntgenstr 2011; 183: $743-748$

8 Sommer A, Lenzen H, Blaser D et al. Prüfanleitung für die Durchführung der ergänzenden Prüfpositionen nach EPQC 4th Edition für digitale Mammografie-Systeme - Leitfaden der deutschen Referenzzentren für Mammografie: Version 1.4. Fortschr Röntgenstr 2009; 181: $845-850$ 
9 Perry $N$, Broeders $M$, de Wolf C et al. European guidelines for quality assurance in breast cancer screening and diagnosis 4th Edition; 2006

10 van Engen RE, Bosmans $H$, Dance DR et al. Digital mammography update. European protocol for the quality control of thephysical and technical aspects of mammography screening. S1, Part 1: Acceptance and constancy testing. In: Perry N, Broeders M, de Wolf C et al. (eds.) European guidelines for quality assurance in breast cancer screening and diagnosis. Fourth edition, Supplements Luxembourg: European Commission, Office for Official Publications of the European Union; 2013: $1-54$

11 Robson KJ. A parametric method for determining mammographic $\mathrm{X}$-ray tube output and half value layer. The British Journal of Radiology 2001; 74: 335-340

12 Dance DR, Skinner CL, Young KC et al. Additional factors for the estimation of mean glandular breast dose using the UK mammography dosimetry protocol. Phys Med Biol 2000; 45: 3225-3240

13 Dance DR, Young KC, van Engen RE. Estimation of mean glandular dose for breast tomosynthesis: factors for use with the UK, European and IAEA breast dosimetry protocols. Phys Med Biol 2011; 56: 453-471
14 Dance D, Young $K$, van Engen $R$. Further factors for the estimation of mean glandular dose using the United Kingdom, European and IAEA breast dosimetry protocols. Phys Med Biol 2009; 54: 4361-4372

15 Bundesministerium für Umwelt, Naturschutz und Reaktorsicherheit RS II 3. Vollzug der Röntgenverordnung: Rundschreiben vom 27. Februar 2008

16 Normenausschuss Radiologie (NAR). DIN 6868-57; Sicherung der Bildqualität in röntgendiagnostischen Betrieben Teil 57: Abnahmeprüfung an Bildwiedergabegeräten. Februar 2001

17 Thijssen MAO, Bijkerk KR, Van der Burght RJM. Manual Contrast-Detail Phantom Artinis CDMAM type 3.4. Section Clinical Physics Department of Radiology University Medical Center Nijmegen and Artinis Medical Systems. 2006

18 Young KC, Cook JJH, Oduko JM et al. Comparison of software and human observers in reading images of the CDMAM test object to assess digital mammography systems. In: Flynn MJ, Hsieh J (eds) Proceedings of SPIE Medical Imaging 2006, 614206: 1-13 